\title{
Impact of the assist ventilation mode on work of breathing (WOB): neurally adjusted ventilatory assist (NAVA) versus pressure support ventilation (PSV) versus proportional assist ventilation plus (PAV+)
}

\begin{abstract}
R Di Mussi ${ }^{1 *}$, S Spadaro², CA Volta ${ }^{2}$, T Stripoli $^{1}$, A Armenise ${ }^{1}$, L Pisani ${ }^{1}$, RG Renna ${ }^{1}$, A Civita ${ }^{1}$, G Altamura ${ }^{1}$, F Bruno ${ }^{1}$, S Grasso ${ }^{1}$
\end{abstract}

From ESICM LIVES 2015

Berlin, Germany. 3-7 October 2015

\section{Introduction}

During assisted mechanical ventilation, appropriate WOB prevents diaphragm atrophy and fastens weaning. During PSV the ventilator support is fixed, irrespective of the patient's effort. On the contrary, both the NAVA and PAV + algorithms are designed to amplify patient's spontaneous effort. [1], [2]

\section{Objectives}

To test if the assist ventilation mode algorithm has an impact on patient's WOB.

\section{Methods}

In 12 patients NAVA, PSV and PAV+ were randomly applied in a crossover fashion, for 4 hours each. The

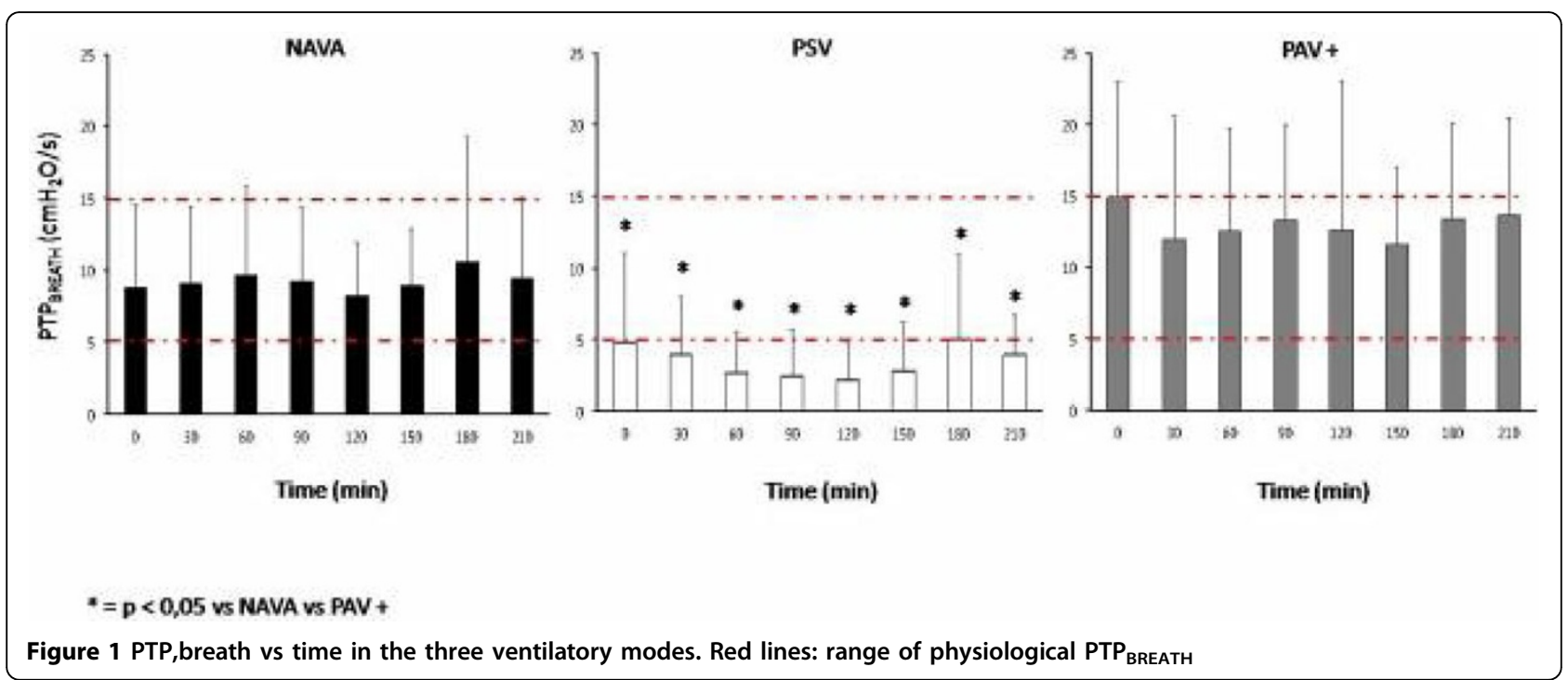

'Università degli Studi di Bari 'Aldo Moro', Dipartimento dell'Emergenza e dei

Trapianti d'Organo, Bari, Italy

Full list of author information is available at the end of the article

(c) 2015 Di Mussi et al.; This is an Open Access article distributed under the terms of the Creative Commons Attribution License (http:// creativecommons.org/licenses/by/4.0), which permits unrestricted use, distribution, and reproduction in any medium, provided the original work is properly cited. 
electrical diaphragmatic activity (EAdi) was continuously recorded during all the modes. WOB per breath (WOBBREATH) was estimated by converting the EAdi pressure time product (PTP)/breath in muscular PTP/breath $\left(\mathrm{PTP}_{\text {BREATH }}\right)$. The conversion factor was the ratio between EAdi peak and airway opening pressure negative peak during an end-expiratory occlusion.

\section{Results}

See figure 1

\section{Conclusions}

PTP $_{\text {BREATH }}$ was in the physiological range during NAVA and PAV + whereas during PSV remained constantly below it. We speculate that, as compared to PSV, NAVA and PAV+ favored a correct matching between diaphragm contraction and ventilator assistance. Further studies are required to test if the WOB pattern during assisted ventilation has an impact on mechanical ventilation duration and other clinically meaningful outcome parameters.

\section{Authors' details}

'Università degli Studi di Bari 'Aldo Moro', Dipartimento dell'Emergenza e dei Trapianti d'Organo, Bari, Italy. ${ }^{2}$ Università di Ferrara, Department of

Morphology, Surgery and Experimental Medicine, Ferrara, Italy.

Published: 1 October 2015

\section{References}

1. Sinderby C, Navalesi P, Beck J, Skrobik Y, Comtois N, Friberg S, Gottfried SB, Lindström L: Neural control of mechanical ventilation in respiratory failure. Nat Med 1999, 5(12):1433-6, Dec.

2. Younes M: Proportional assist ventilation, a new approach to ventilatory support. Theory Am Rev Respir Dis 1992, 145(1):114-20, Jan.

3. Bellani G, Mauri T, Coppadoro A, Grasselli G, Patroniti N, Spadaro S, Sala V, Foti G, Pesenti A: Estimation of patient's inspiratory effort from the electrical activity of the diaphragm. Crit Care Med 2013, 41(6):1483-91, Jun.

doi:10.1186/2197-425X-3-S1-A9

Cite this article as: Di Mussi et al:: Impact of the assist ventilation mode on work of breathing (WOB): neurally adjusted ventilatory assist (NAVA) versus pressure support ventilation (PSV) versus proportional assist ventilation plus (PAV+). Intensive Care Medicine Experimental 2015 3(Suppl 1): A9.

\section{Submit your manuscript to a SpringerOpen ${ }^{\circ}$ journal and benefit from:}

- Convenient online submission

- Rigorous peer review

- Immediate publication on acceptance

- Open access: articles freely available online

- High visibility within the field

- Retaining the copyright to your article

Submit your next manuscript at $\gg$ springeropen.com 